\title{
Increasing Knowledge Of Electric Hazards And Their Mitigation For Residents Of The Rw 15, Ciwaruga Village, Parongpong District, West Bandung
}

\author{
ACHMAD MUDAWARI, AHMAD DENI, ALI MASHAR, ACENG DAUD, \\ SITI SAODAH, ERWIN YUSUF, TEGUH SASONO
}

Teknik Konversi Energi Politeknik Negeri Bandung

Email : siti.saodah@polban.ac.id

Received 10 November 2021 | Revised 11 November 2021 | Accepted 16 November 2021

\begin{abstract}
Electricity is needed by the community because it is easily converted into other forms of energy. Electricity is very useful but at the same time dangerous for humans if they do not have the knowledge, understanding and skills about it. This training was carried out with the aim of providing knowledge about electrical hazards and skills in electrical installation for residents of RW 15, Ciwaruga Village, Parongpong District. With the materials and methods and approaches applied, the training can run smoothly and work well. This success is shown by the active participation and high enthusiasm of the participants during the training and the high level of absorption of the training materials delivered. This is reflected in the increase in knowledge and skills in terms of making good installations as indicated by the increase in the value of the final test results (posttest). In addition, this paper can also be used as a reference for parties who will carry out similar or other activities related to electrical installations.
\end{abstract}

Keywords: Electrical hazard, installation modules, methods, approach systems.

\section{INTRODUCTION}

Electricity is one source of energy that is needed by the community because it is easily converted into other forms of energy. However, it is not uncommon for electricity to be a source of disaster that can cause havoc for humans either due to shocks, fires, and explosions. The shock occurs due to the contact of members/parts of the human body with live parts of the installation and fires because of short circuits, overloads, leakage currents and arc-flash. To prevent unwanted things from electricity, understanding the dangers of electricity and its installation is very important, especially for electricity users themselves.

Considering how important an understanding of electricity is, so it is necessary to provide understanding as well as skills for the community, especially in the RW 15 residents, Ciwaruga Village, Parongpong District, West Bandung Regency about electricity hazards and their mitigation as well as electrical installation skills. The partner's average level of education is high school and the majority of his occupations are construction workers 
Touch voltage can occur due to contact between parts of the human body, either directly or indirectly, with parts of a live electrical installation which causes current to flow from the voltage part through the human body to the earth (Zarniadi, 2019) (Sunarto, 2017) (Djuardresni Patabang, 2017). This event can endanger humans with mild to severe impacts and can even cause death. The impact of touch voltage can be avoided if the public understands electrical hazards and their mitigation.

\section{Electrical hazards to humans and their mitigation}

The impact of electric current flowing through the human body can be divided into 4 categories as shown in Figure 1. To understand the impact of electric shock on humans it has been described in international standards (IEC, 2018), as illustrated in Figure 1. This figure explains that there are two factors that influence the impact of electric shock on humans, namely the magnitude of the electric current and the time of the shock, where the greater the electric current flowing into the body and the longer the shock time the consequences are more severe. There is one other important factor, namely the electrical pathways in the body. Like the trajectory that hits the heart and lungs and the nerve center (head) (Mashar, 2019).

Based on Figure 1, the impact of electric current flowing through the human body is divided into 4 categories, namely Zone 1 (not felt), Zone 2 (safe), Zone 3 (dangerous) and Zone 4 (fatal).

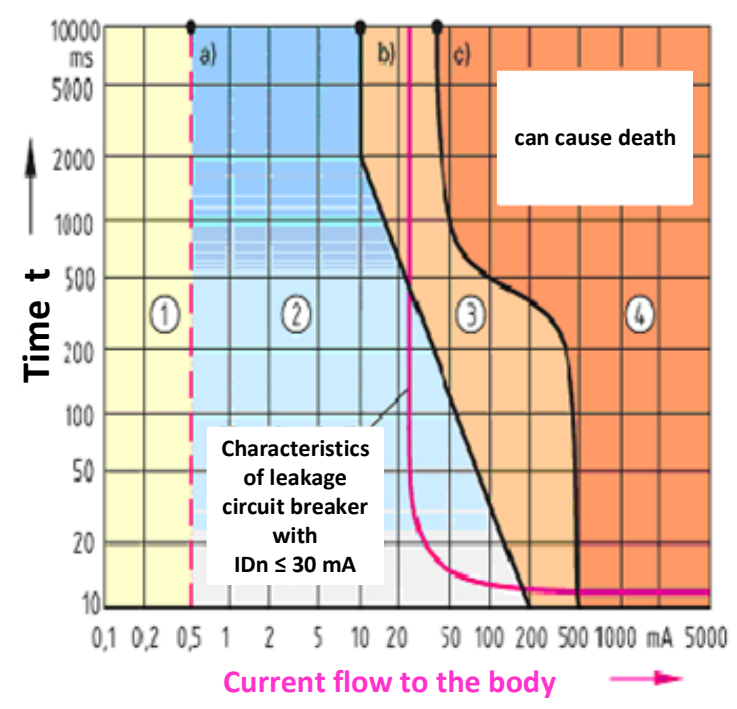

Figure 1. The Hazards of Electric Current to the Human Body

Some explanations of these curves (Figure 1) are given below. 
Table 1. The Hazards of Electric Current to the Human Body (PLN, Peraturan Umum Instalasi Listrik (PUIL), 2011)

\begin{tabular}{|c|c|l|}
\hline Zone & Current (mA) & Body Reaction \\
\hline 1 & $0,1-0,5$ & Not felt, or just a sensation \\
\hline 2 & $0,5-10$ & $\begin{array}{l}\text { The shock has been felt but has not } \\
\text { caused health problems }\end{array}$ \\
\hline 2,3 & $20-50$ & $\begin{array}{l}\text { It becomes dangerous when the time is } \\
\text { up to 0.5 seconds. } \\
\text { Becomes dangerous when the time } \\
\text { reaches 0.01 seconds and turns fatal } \\
\text { when it reaches 1 second }\end{array}$ \\
\hline 3 & $200-500$ & $\begin{array}{l}\text { Very dangerous zones (muscle spasms, } \\
\text { respiratory distress, etc.). 200 mA if } \\
\text { more than 0.4 second enter the fatal } \\
\text { area (death) }\end{array}$ \\
\hline 4 & 500 above & $\begin{array}{l}\text { Almost certainly the occurrence of heart } \\
\text { failure (stops beating) }\end{array}$ \\
\hline
\end{tabular}

The model for the flow of electric current to the human body can be described as shown in Figure 2 below:
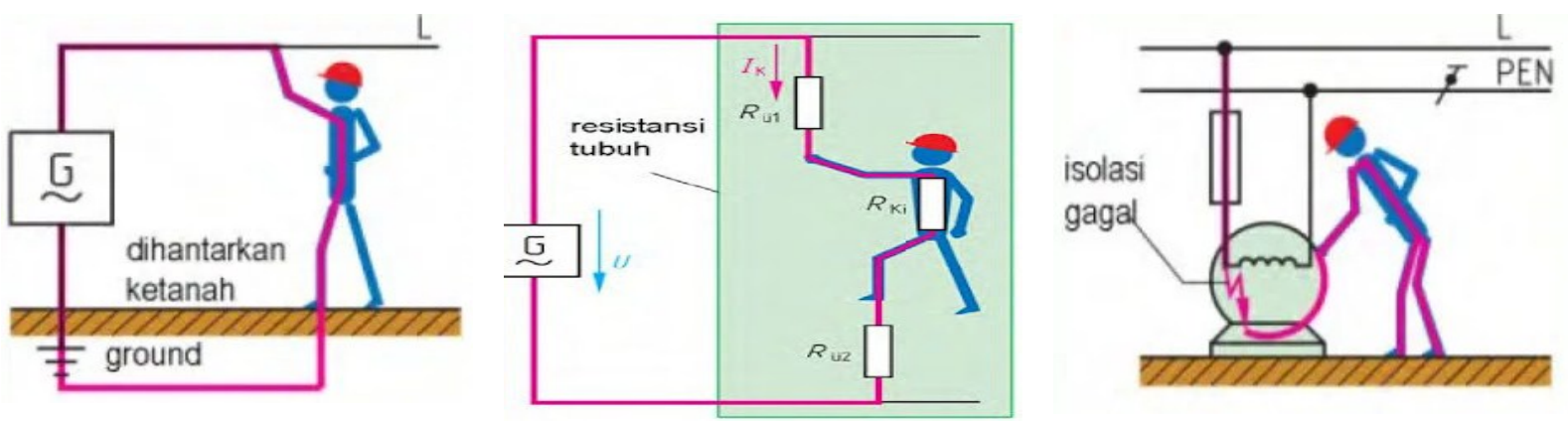

Figure 2. Illustration of Touch Voltage (Sukardi, 2019) (Coory, 2010) (Bunning, 2019) with:

$R_{01} \quad$ Touch resistance $(\Omega)$

$R_{K i} \quad$ Human body resistance $(\Omega)$

$R_{02} \quad$ Foothold resistance $(\Omega)$

$R_{K} \quad$ Total resistance $(\Omega)$

$I_{K} \quad$ Electric current $(\mathrm{A})$

$U_{B} \quad$ Touch voltage (V)

So

$$
\begin{gathered}
I_{K}=\frac{U_{B}}{R_{K}} \\
R_{K}=R_{01}+R_{K i}+R_{02}
\end{gathered}
$$


The flow of $I_{K}$ current that passes through the human body is influenced by the amount of resistance $R_{K}$ in the path that the current passes. Humans have an average $R_{K i}$ resistance of $1000(\Omega)$, so that if a part of the human body is connected to a $220 \mathrm{~V} \mathrm{AC} \mathrm{low-voltage}$ electrical installation line and is connected directly to the earth as illustrated in Figure 2, in the human body will flow a current of 0, $22 \mathrm{~A}$. From Figure 1, this magnitude of current is in zone 4 which can be fatal and can cause death.

To avoid the impact of this touch voltage, then:

1. Electrical installations and installed equipment must be standard and equipped with a leakage current safety system to the earth by using an Earth-Leakage Circuit Breaker (ELCB) or Residual Current Circuit Breaker (RCCB) (PLN, Peraturan Umum Instalasi Listrik (PUIL), 2011) (Sukardi, 2019). The open conducting section (BKT) of each equipment must be grounded.

2. In carrying out professional electrical installations, technical personnel must have a certificate of competence using standard work equipment and Personal Protective Equipment (PPE) such as gloves, shoes and electrical safety helmets (ESDM, 2014) (PLN, Peraturan Umum Instalasi Listrik (PUIL), 2011) (PLN, UU Tentang Ketenagalistrikan, 2009).

\section{Electric fire hazard}

The rate of fires in Indonesia is still so high and it is suspected that most of them are caused by electricity. In Indonesia's capital city, Jakarta, fires caused by electricity account for more than $74 \%$ (Nisa, 2019).

This phenomenon proves that the quality of electrical installations is still low. The low quality of electrical installations is caused by many factors, including the quality of the installation components, installations and installations that are too old and not properly maintained. In this regard, the government has regulated electrical installations through laws and regulations such as the Indonesian National Standard (SNI) or the 2011 General Electrical Installation Regulations (PUIL).

Electrical installations must be reliable, safe and environmentally friendly (PLN, Law on Electricity, 2009). Therefore, each installation must have a Letter of Appropriate Operation (SLO) from the authorized institution.

\section{METHODOLOGY}

The implementation method that will be carried out for community service in the Ciwaruga community is to depart from the approach to the analysis of the situation encountered and agreed upon by the Partners as a form of solution offered. Figure 3 show Methods of Implementation of Community Service.
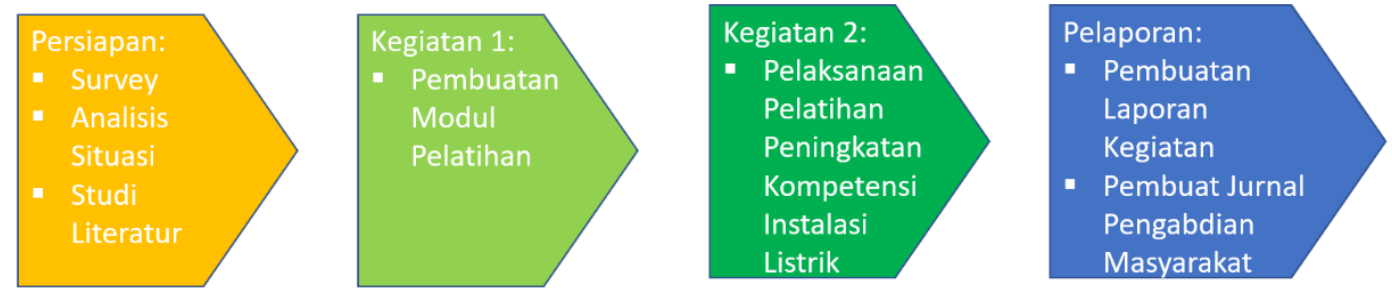

Figure 4. Methods of Implementation of Community Service in Ciwaruga Village 
The stages of PKM activities begin with site surveys, coordination with partners, literature studies, then proceed with the preparation of tools and materials, manufacture of training modules, and implementation of the training.

Considering the situation and condition of the pandemic that was still ongoing at the time of implementation, this activity was carried out in a mixed manner, namely online and offline. The implementation of offline activities is facilitated by the community by utilizing the Madrasah building as a place of activity.

To achieve the goal of increasing knowledge of electrical hazards and skills in terms of installation, the following training methods have been prepared and agreed upon:

a. Pretest: The pretest was conducted at the beginning of the training. This pretest is intended to determine the participants' basic understanding of the substance of the training.

b. Lectures and discussions; This is a process of delivering material that has been designed to discuss the problems that arise by prioritizing the interactive method.

c. Practice: At this stage, participants are directly involved in practicing the concepts that have been discussed in theory using the modules that have been prepared including the measuring instruments. At this stage the participants are also given knowledge about the materials as well as make the correct installation in order to avoid the dangers that may arise.

d. Posttest: This activity is the final process in the training, namely the measurement of learning achievement so that the effectiveness of the training can be known.

\section{RESULTS AND DISCUSSION}

Evaluation is carried out to see the success of the training that has been held. This evaluation was carried out based on the pretest and posttest processes to the trainees.

Figure 4 and Figure 5 respectively show the results of the pretest and posttest of the 12 training participants who participated in the activity from beginning to end. This graph illustrates the participants' understanding of the 15 questions given. From this picture it can also be seen that after the training there was an increase in understanding of each of the questions given.

While Table 2 describes the percentage of correct and incorrect answers both pre-test and post-test. From this picture, it can also be seen that there was an increase in correct answers from the previous $41.11 \%$ to $64.44 \%$. Thus, it can be concluded that with this training there was an increase in the participants' understanding of the electrical training lesson provided. 


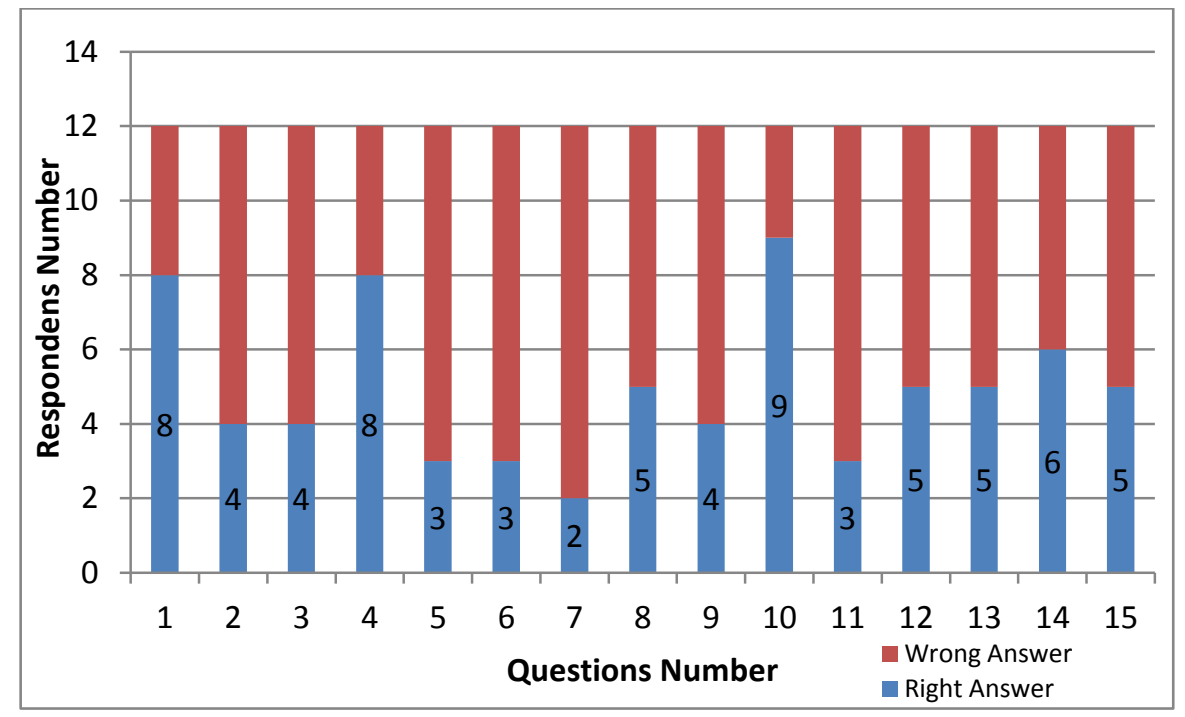

Figure 5. Pre-Test Results for each Question Number

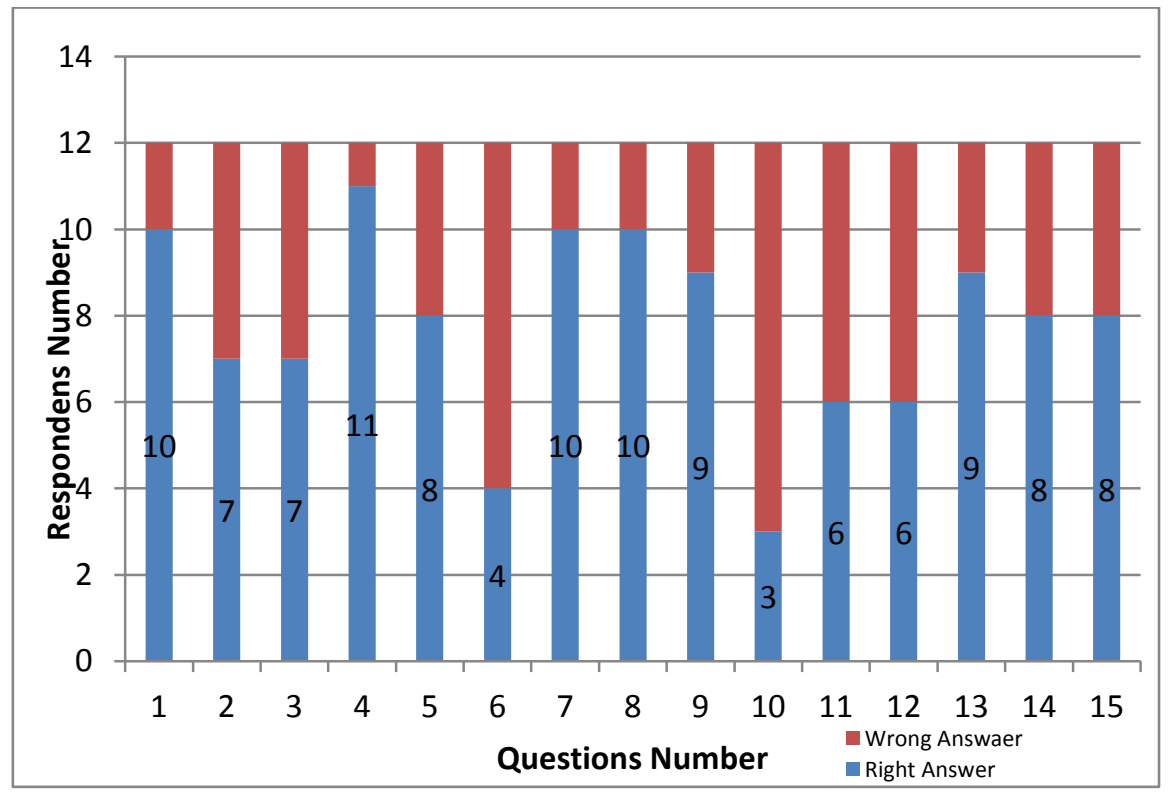

Figure 6. Hasil Post Test tiap Nomor Soal

Table 2. Minimum, maximum and percent correct answers for Training Participants

\begin{tabular}{|l|c|c|}
\hline \multicolumn{1}{|c|}{ Nilai } & Pre-Trest & Post-Test \\
\hline Minimum & 2 & 3 \\
\hline Maksimum & 9 & 11 \\
\hline Percent of Correct Answers & $41,11 \%$ & $64,44 \%$ \\
\hline
\end{tabular}

Figure 7 below provides a visual illustration of the atmosphere of the training activities delivered. 


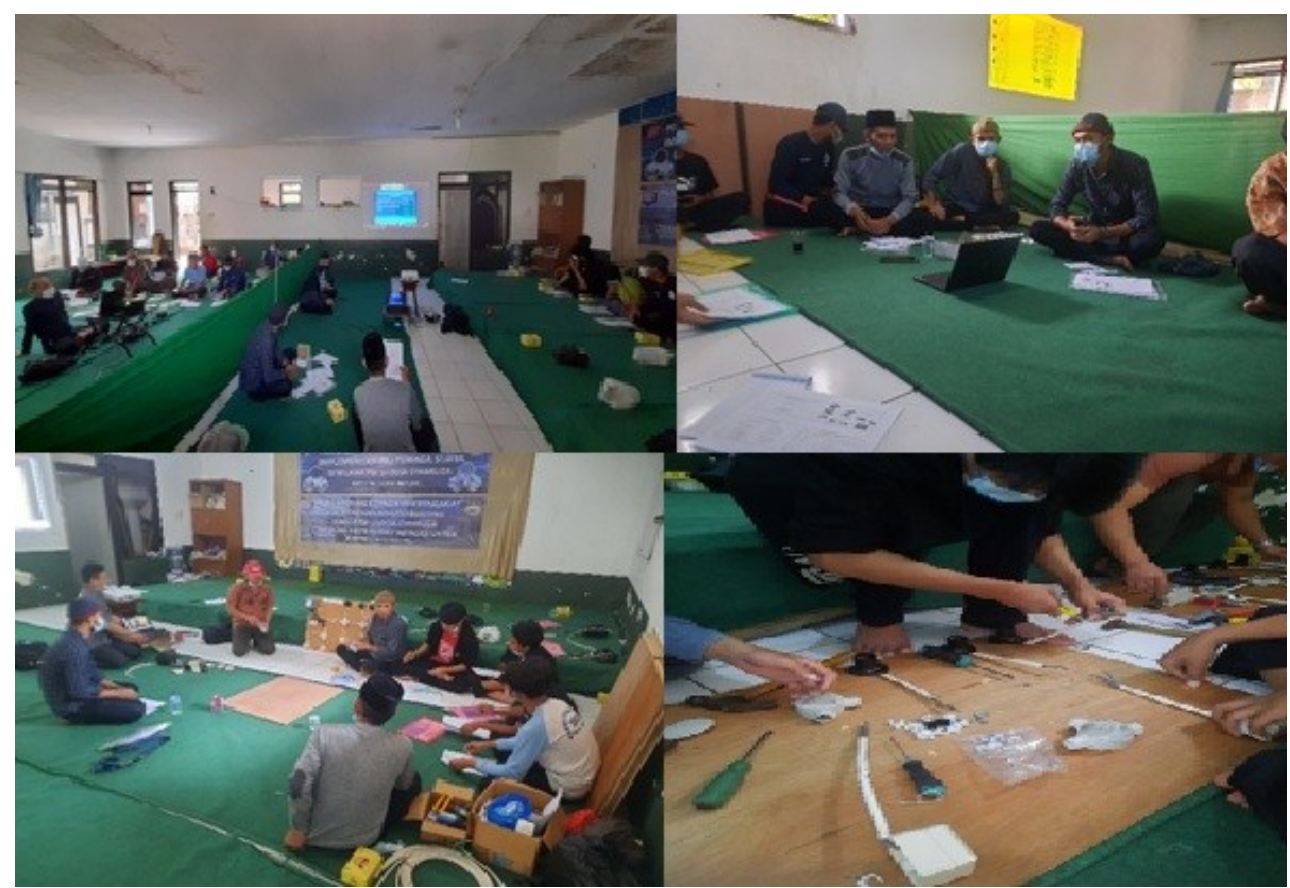

Figure 7. Training Atmosphere

\section{CONCLUSIONS}

This training has been able to increase the participants' knowledge and understanding of the electrical material provided about electrical hazards to humans and their mitigation, this is indicated by an increase in the correct answers to questions from the original $41.11 \%$ to $64.44 \%$.

\section{ACKNOWLEDGEMENT}

The author would like to express his deepest gratitude for the help of those who cannot be written one by one. Our gratitude goes to the Center for Research and Society Service (Pusat Penelitian dan Pengabdian - P3M) of the Bandung State Polytechnic for funding, encouraging, initiating, and educating young researchers to develop and follow the development of research activities and community service in Indonesia and the world.

\section{REFERENCES}

Bunning. (2019). TVET Teacher Education Curriculum. The Third International Conference on Innovation in Engineering and Vocational Education.

Coory, C. G. (2010). Surge Protection of Low Voltage System and Relevant Standard. 30 th International Converence on Lightning Protection. Italy: Cagliari.

Djuardresni Patabang, T. P. (2017). Pelatihan Pengembangan PLTMH Berbasis Masyarakat Mandiri. Jurnal Pengabdian Papua, ISSN 2550-0082, 1-6. 
ESDM, P. M. (2014). Tingkat Mutu Pelayanan dan Biaya yang Terkait dengan Penyaluran Tenaga Listrik. Jakarta: PT.Perusahaan Listrik Negara (PERSERO).

IEC, 6.-1. (2018). Basic guidance on the effects of shock current on human beings and livestock. International Standar.

Mashar, A. (2019). Keselamatan dan Kesehatan Kerja. Bandung: Jurusan Teknik Konversi Energi, Polban.

Nisa, K. (2019). Kejadiian Kebakaran Beserta Jumlah Kerugian, Korban dan Penyebab Tahun 2019. Jakarta: Badan Penanggulangan Bencana Daerah DKI Jakarta.

PLN. (2009). UU Tentang Ketenagalistrikan. Jakarta: PT. Perusahaan Listrik Negara (PERSERO).

PLN. (2011). Peraturan Umum Instalasi Listrik (PUIL). Jakarta: PT. Perusahaan Listrik Negara.

Sukardi, F. D. (2019). Protoptipe Pengaman Peralatan Listrik dan Tegangan Sentuh Bagi MAnuasia dengan ELCB. Jurnal Teknologi Elektronika, 50-56.

Sunarto. (2017). Analisa Pengaruh Resistansi Elektrode Pembumian Pada Sistem TT Terhadap Bahaya Tegangan Sentuh. Perpustakaan Polban, 1-5.

Zarniadi, W. (2019). Analisa Tegangan Sentuh dan Tegangan Langkah di Gardu Induk 150 KV Batu Besar menggunakan System Grid. Jomfteknik, (6), 1-6. 